Sedat Benek (D)

Harran University, Turkey

Recep Baydemir (D)

Harran University, Turkey

\title{
PROBLEMS ENCOUNTERED BY THE SYRIANS IN THE CONTEXT OF CULTURAL CONFLICT AND INTEGRATION: A CASE STUDY OF ŞANLIURFA CITY
}

\begin{abstract}
The process that started with a demonstration against the regime on 15 March 2011 spurred by desire to reform Dera/Syria quickly turned into a civil war. The resulting forced immigration presented Turkey with the challenge of one of history's largest immigration movements. Turkey adopted open door policy towards Syrians and gave them temporary protection status. Thus the Syrians were considered to be guests of Turkey until they could return to their homeland. However, internal disturbances in Syria became increasingly complex and the Syrians' stay turned into a long-term one. As the case of Şanlıurfa city demonstrates, there are significant cultural differences between the Syrian immigrants and the indigenous people, which include clothing, traditions, customs, attitudes and behaviours. They make integration of both peoples difficult and cause a serious cultural clash between the local people and the Syrians in the city. These emerging problems inspired this research, which aims to showcase the problems of socio-cultural integration of the Syrians through a case study of Şanliurfa city and to examine the factors underlying these problems.
\end{abstract}




\section{Key words}

Turkish-Syrian relations, civil war, cultural conflict, social exclusion, discrimination

\section{Introduction}

In December 2010, a young person named Mohammad Bouazizi attempted suicide in Tunisia by burning himself; this event became a spark that soon spread to the entire Arab world, especially Egypt, Libya and Syria, but also influenced such countries as Algeria, Jordan, Bahrain and Yemen. This process, called the Arab Spring, led to regime changes in some countries, while in others internal disturbances are still continuing (AFAD, 2017a, p. 11). Undoubtedly, one of the countries most strongly affected by the Arab Spring was the Syrian Arab Republic. What started with a demonstration against the regime in the city of Dera on 15 March 2011 soon transformed into a civil war.

As a result, millions of people have been forced to migrate within the country or across its borders: approximately 9 million people had to resettle within Syria, and according to the data received from The Office of the United Nations High Commissioner for Refugees (UNHCR), as of 19 July 192018 5,600,199 people were forced to leave Syria (UNHCR, 2018). The vast majority of Syrians who had to migrate abroad chose Turkey due to its proximity across the border and the open door policy adopted towards Syrians (Benek, Elmastaş, Özcanlı, \& Pinar, 2017, p. 192; Benek \& Pinar, 2016, pp. 2095-2096) (Photo 1). The first group of 260 Syrians fleeing war arrived in the town of Yayladağ ${ }_{1}$ in Hatay province on 29 April 2011 (AFAD, 2017); as the conflict in Syria became increasingly violent, people began to emigrate in droves.

Turkey adopted the open door policy towards the Syrians and gave them "temporary protection" status in accordance with international refugee law and international conventions: until the situation in Syria returned to normal, the Syrians were to remain guests of Turkey. However, as it could be expected, the internal turmoil in Syria did not end quickly, becoming increasingly complicated instead, which compelled the Syrians to remain in Turkey. 
Photo 1. A group of Syrians escaping the civil war in their country to take refuge in Turkey

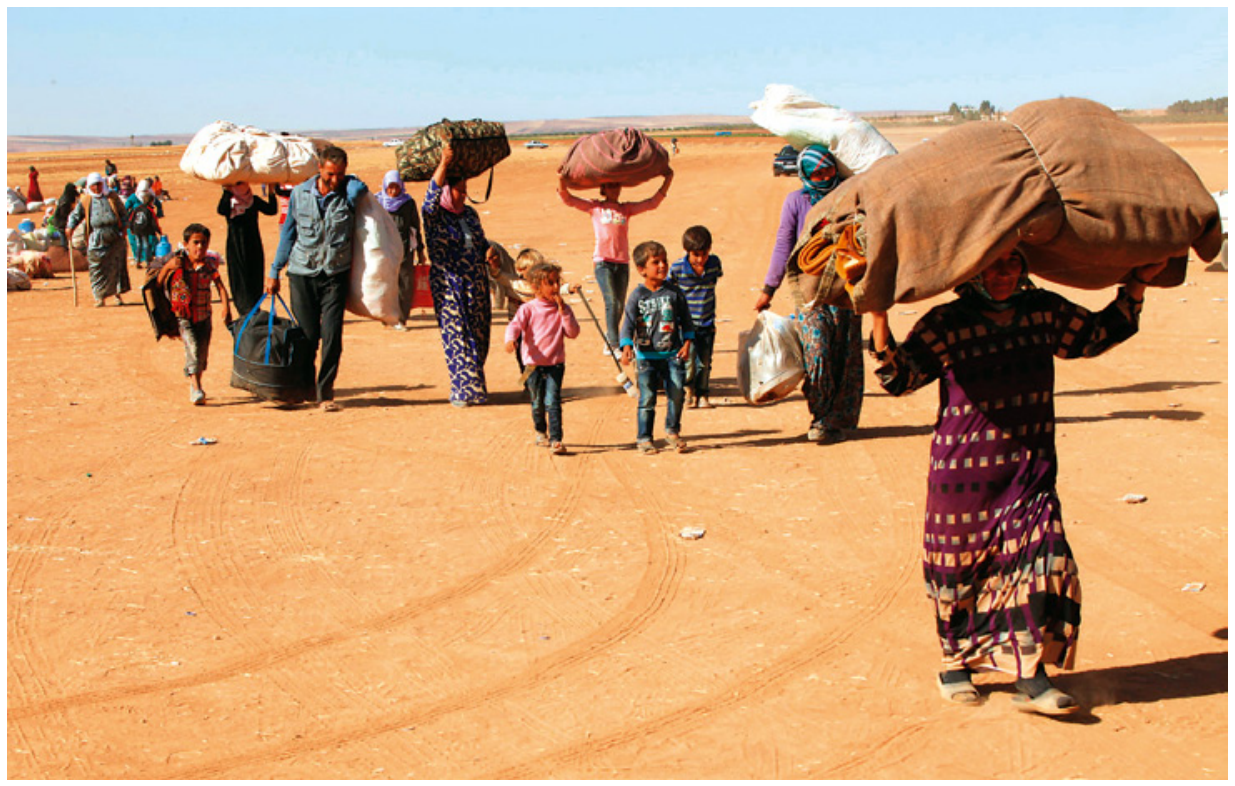

Source: Gutman, 2016.

The majority of the Syrians - over 3.5 million out of approximately 5.6 million who had to migrate out of the country - moved to Turkey. 471 thousand of them chose the province of Şanliurfa, most likely due to its geographical proximity or in order to join their relatives and acquaintances who had already moved there. According to the Immigration Administration data from July 2018, after Istanbul (563,791 people) the second largest population of Syrians was located in Şanlıurfa province (471,955 people), and 29\% (131 thousand) of them resided in Şanlıurfa city (Benek et al., 2017, p. 192). According to the data from the Turkish Statistical İnstitute (TÜİK) for 2017, the population of Şanliurfa province was $1,985,753$ and the population of Şanliurfa city was 700,000. Such massive influx of immigrants to Şanlıurfa province has negatively affected the area - and the city in particular - sociologically, culturally and economically. On the one hand, the Syrians experience problems with social integration in the city; on the other hand, they face numerous problems when trying to support themselves and in this sense they continue to suffer economic hardship. Both the Syrians living in the camps and the Syrians living among the local population encounter basic problems considering such matters as access to shelter, proper nutrition, health services and education. Thus a study on the Syrians in Şanlıurfa (see 
Benek et al., 2018a; Benek et al., 2018b; Benek et al., 2017) proved that for more than half of the Syrians "economy" was the most troubling issue, together with "language and communication".

Moreover, what causes serious conflicts between the Syrians and the indigenous people are basic cultural differences, such as traditions (including even styles of clothing), as well as attitudes and behaviors (Benek et al., 2018a, p. 344). All these differences increase the polarization between the two peoples; making integration difficult, they lead to the emergence of cross-cultural problems that can result in "discrimination", "otherization" and "social exclusion". Ultimately, the arising problems prevent peaceful co-existence of the two groups. The importance of this issue to the future of both countries and coexistence of the two nations motivated my research.

Using Şanlıurfa city as an example, this study aims to define the problems of the socio-cultural integration of the Syrians and to examine the factors underlying these problems. After a brief description of the research, information will be given regarding the situation of the Syrians in Şanlıurfa city, followed by explanation of such concepts as immigration, refugees, asylum seekers and integration. Then problems that the Syrians have encountered in this context will be discussed. The text will conclude with an attempt to apply the concepts of "living together", "social exclusion" and "cultural conflict" to the analysis of a field study in Şanlıurfa city.

\section{Literature Review}

First of all, there are numerous studies in the national and international literature on migration. In the foreign literature, the research of Stephen Castles (2002; 2003; 2004; 2009; 2010; 2012; Castles et al. 2013; Castles \& Kosack 1973; Castles \& Davidson 2000;), Franck Duvel, Bill Jordan (Jordan \& Duvel, 2002), Stephen Legomsky (1987), Aspasia Papadopoulou-Kourkoula (2008) Franck Duvel (2004a; 2004b; 2005a; 2011a; 2006b; 2008; 2009; 2011a; 2011b; 2012), Hein De Haas (2010) and Christian Joppke (1998) is considered to be the most significant and outstanding. In general, Duvel's studies examined the migration phenomenon in Europe and focused on issues such as transit migration, irregular migration, the impact of migration on European countries, relations between migration, economics and politics, and migration policies. Castles is a prominent figure in studies on such issues as globalization and migration, immigration and citizenship, and the failure of migration policies. In addition, the book The Age 
Of Migration: International Population Movements In The Modern World (2013), written by Castles, Hein De Haas and Mark J. Miller is one of the most useful and most frequently cited books on migration. This study was translated into Turkish as Gocler Cagi: Modern Dünyada Uluslararası Göç Hareketleri. As the title implies, Castles and his friends call our times the age of modern migration and underline the relationship between globalization and migration.

Among Turkish literature, important texts include the book Küreselleşme Çağında Göç: Kavramlar Tartışmalar [The Age of Globalization Migration: Concept Debates] (2016) edited by Gulfer Ihlamur-Oner and Aslı Sirin Oner as well as Inan Keser’s Göç ve Zor: Diyarbakır Örneğinde Göç ve Zorunlu Göç [Migration and Difficulties: Migration and Forced Migration in the Case of Diyarbakir] on forced migration resulting from violence and conflict in Turkey's East and Southeast region in the 1990s. Other significant books are Cemal Yalcin's Göç Sosyolojisi [Sociology of Migration] (2004) and Yusuf Adıgüzel's book (2016) bearing the same title; both works use the sociological approach to examine the phenomenon of migration.

The mentioned studies are important works dealing with the migration phenomenon in general at both national and international level. However, with the outbreak of the Syrian Civil War, many academic studies focused on Syrian migrants who had to leave their country due to the events in Syria, and on the background of these events and the conflicts in the region. Such studies include John McHuga's Syria: From the Great War to Civil War (2014) and Syria: A Recent History (2015); Nicolaos Van Dam's Destroying a Nation: The Civil War in Syria (2017); and Robin Yassin-Kasap and Leila Al Shami's Burning Country: Syrians in Revolution and War (2016). However, the studies listed here focus mostly on the Syrian Civil War, which turned into a spiral of violence, and on people who had to flee.

On the other hand, it is also useful to refer to some studies on the Syrians forced to emigrate to Turkey by the Syrian Civil War. Outstanding texts include Mahmut Kaya's book Türkiye'deki Suriyeliler: İç İçe Geçişler ve Karşılaşmalar [Syrians in Turkey: Nested Transition and Encounters] (2017), and his article "Komşuda Misafirlik: Suriyeli Sığınmacılarca Kurulmuş Mülteci Derneklerinin Perspektifinden Türkiye'de Yaşamak" [Hospitality of a Neighbor: Living in Turkey from the Perspective of Syrian Refugees' Association] (2015); Ahmet Koyuncu's book Kentin Yeni Misafirleri Suriyeliler [The city's new residents: Syrians] (2014); Kemal Kirisci’s report Misafirliğin Ötesine Geçerken Türkiye’nin Suriyeli Mülteciler Sınavı [Hospitality Beyond Passing Turkey's Syrian Refugees Examination] (2014); Murat Erdogan's report “Türkiye'deki Suriyeliler: 
Toplumsal Kabul ve Uyum Araştırması" [Syrians in Turkey: Social Acceptance and Adaptation Research] (2014); "Kamp Dıı̧ında Yaşayan Suriyeli Kadın Sığınmacilar Raporu", a 2014 report of Mazlumder organisation on Syrian women refugees living outside the camps; and a research report "Entegrasyon Bakımından Suriyelilerin Küçük Esnaf İşgücü Piyasası'na Etkilerinin Araştırılması: Şanliurfa Şehri Örneği” [Investigation of the Effects of Syrians on Small Tradesmen Labor Markets in Terms of Social Integration] by Benek et al.

There are also several international and international studies focusing on "as similation"," discrimination", "otherization" and "social exclusion" in the context of the phenomenon of migration, which include e.g. Ozatesler's Gypsy Stigma and Exclusion in Turkey, 1970: The Social Dynamics of Exclusionary Violence (2014); İçduygu and Şimşek's “Syrian refugees in Turkey: Towards integration policies" (2016); Morrison's “Discrimination and the Abuse of Human Rights Characterises the Current Plight of Palestinian Refugees from Syria" (2014); Terzioğlu's "The banality of Evil and the Normalization of the Discriminatory Discourses Against Syrians in Turkey” (2018); Simsek's “Transnational Activities of Syrian Refugees in Turkey: Hindering or Supporting İntegration” (2018); and two texts by Ülker, "Assimilation of the Muslim Communities in the First Decade of the Turkish Republic (1923-1934)" (2008) and "Assimilation, Security and Geographical Nationalization in Interwar Turkey: The Settlement Law of 1934" (2008).

\subsection{Methodology}

The statistical data in this study were obtained from the General Directorate of Migration Management, the Şanlıurfa Directorate of Migration Management, the Disaster and Emergency Management Presidency of Turkey (Afet ve Acil Durum Yönetimi Başkanlığı, AFAD) and UNHCR.

The area of this study is Turkey's province of Şanlıurfa, and the sample consists of Syrians living in Şanlıurfa city (see Map 1).

The subject of this study are the problems that Syrian people living in Şanliurfa experience in the context of socio-cultural integration and the factors that lead to cultural conflict between the locals of Şanliurfa and the Syrians. In order to uncover these issues, studies and observations were made from the first week of January until the last week of February 2018 in the city neighborhoods (such as Devteşti, Topçu Meydani, Sigorta, Balikligol etc.) where the Syrians constitute a significant part of the population. During the study we had an opportunity to interview and talk with both the locals and Syrians. Within the study's framework, 10 focus group interviews were conducted with 
10 non-governmental organizations and 10 Syrian people. In addition, face-toface interviews were conducted with the leaders of the 5 neighborhoods where the Syrians live. 20 residents of Şanlıurfa were also interviewed in order to discover the local society's perceptions of Syrians. Thus an attempt was made to determine with fieldwork-based interview technique the problems faced by Syrians in the context of cultural conflict and integration. The field research was enriched by drawing on researchers'previous field experience and previous studies conducted in the area.

Map 1. Şanlıurfa's Location

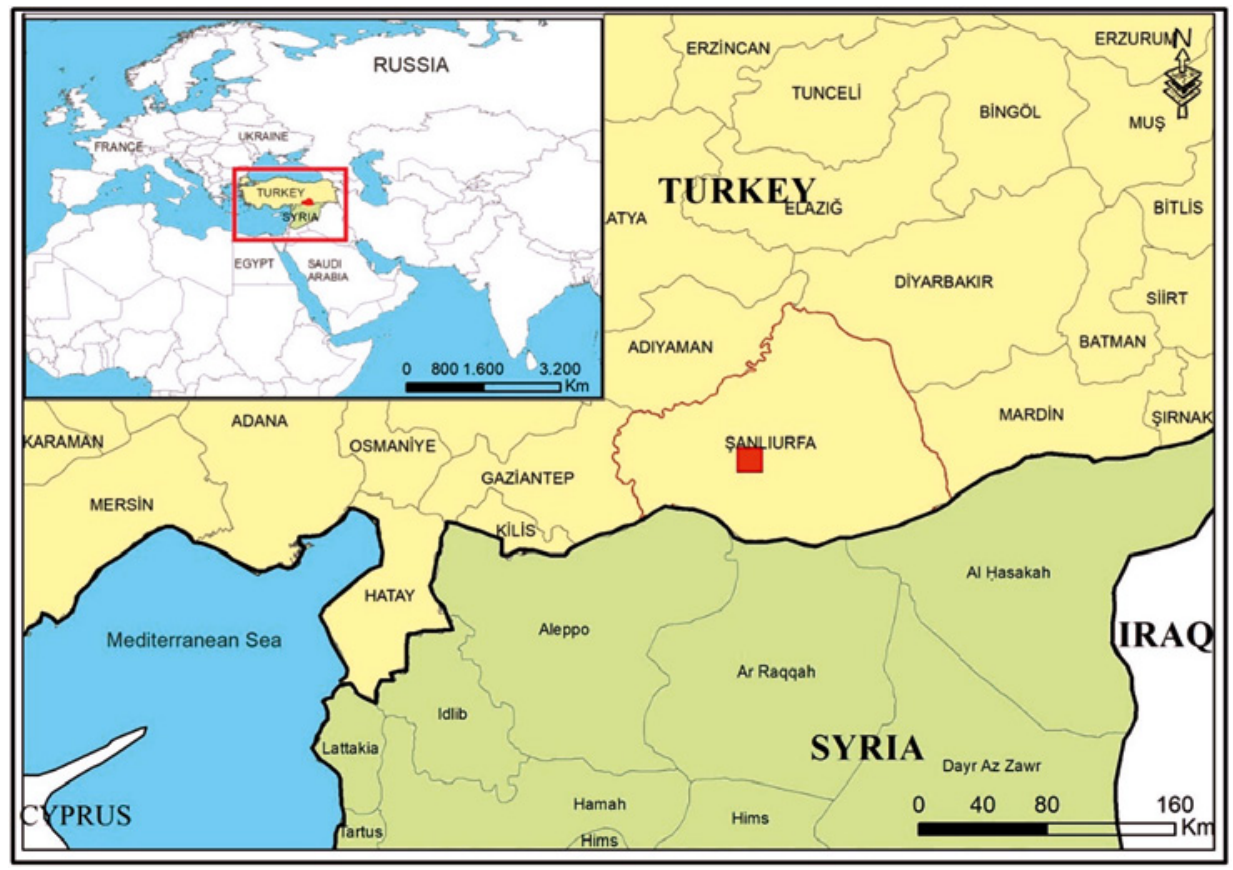

An extensive review of literature on the subject was thus conducted parallel to the field study. The relevant information was collected from such sources as the previous studies on migrants - in particular migrants from Syria - as well as the press and news channels' output reflecting migrant-related issues. Data sets had been compiled for research purposes. In this way, the information gathered from the literature could be presented together with the data obtained in the field study and accompanied by a certain theoretical and conceptual discussion. 


\section{General Situation of Syrians Living in Turkey and Other Countries}

According to data from UNHCR, as of July 19, 2018, 5,600,199 people had been forced to leave Syria. $63.3 \%$ of those who left Syria (3,541,572 people) lived in Turkey, $17.4 \%$ (976,065 people) in Lebanon, $11.9 \%(666,596)$ in Jordan, $4.5 \%$ $(251,157)$ in Iraq, and 2.3\% $(129,737)$ migrated to Egypt (Table 1 and Figure 1).

Table 1. Total number of persons of concern by country of asylum

\begin{tabular}{|c|c|c|c|}
\hline Location name & Date & $\%$ & Population \\
\hline Turkey & 19 Jul 2018 & $63.3 \%$ & $3,541,572$ \\
\hline Lebanon & 30 Jun 2018 & $17.4 \%$ & 976,065 \\
\hline Jordan & 24 Jun 2018 & $11.9 \%$ & 666,596 \\
\hline Iraq & 30 Jun 2018 & $4.5 \%$ & 251,157 \\
\hline Egypt & 30 Jun 2018 & $2.3 \%$ & 129,737 \\
\hline Other (North Africa) & 15 Mar 2018 & $0.6 \%$ & 33,545 \\
\hline
\end{tabular}

Source: UNHCR.

Figure 1. Total number of persons of concern by country of asylum

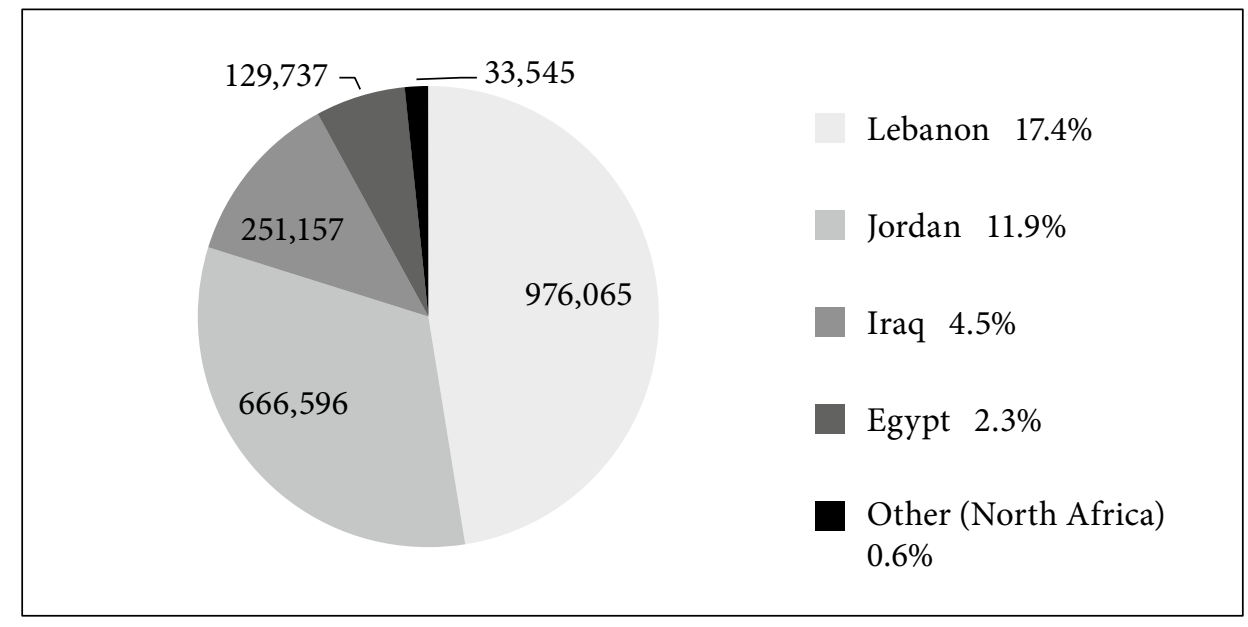


As it can be concluded from the tables, the target locations for migration have been areas close to Syrian borders, where the number of migrants has been increasing. The first priority of the Syrian migrants who escaped from the conflict zone is not to achieve a high standard of living, but to survive and to move to protected areas, preferably those close to their previous homes.

In 2012, a total of 14,237 Syrians were taking shelter in Turkey, within the temporary protection zone (in the Area of Temporary Protection) removed, while by 2018 this figure had reached 3.541.572. The number of Syrians who took refuge in Turkey over the years is presented in the chart below (Figure 2).

Figure 2. Distribution of Syrian refugees in the Area of Temporary Protection by year

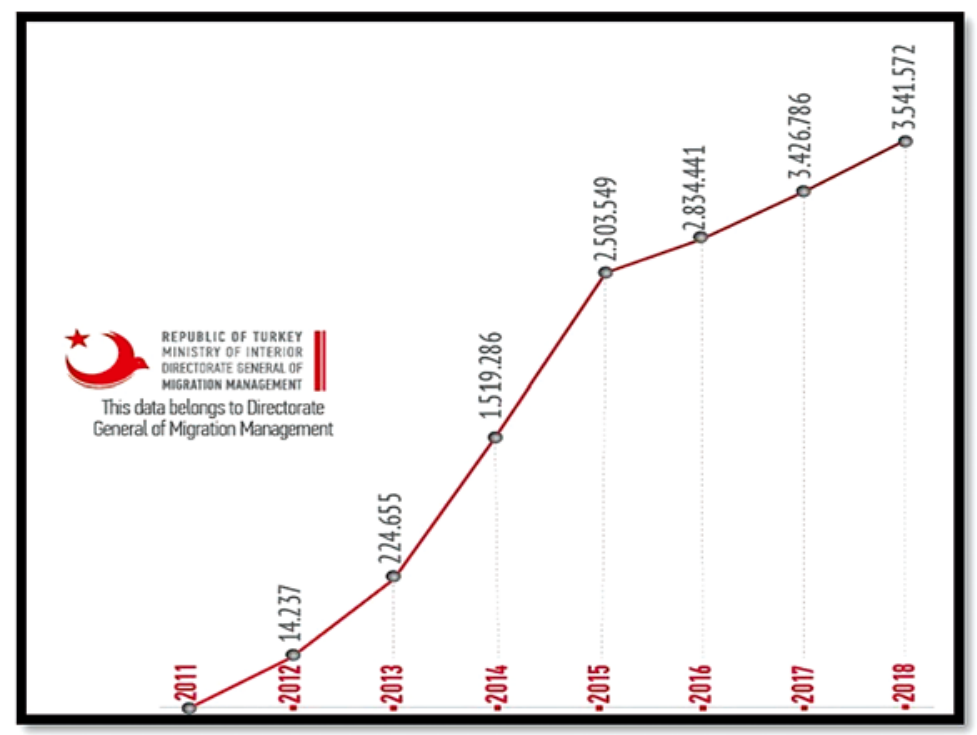

Source: General Directorate of Migration Management, 2018.

As shown in Figure 2, the graph represents a steady upward trend from 2011 to 2018: the number of Syrians who came to Turkey during these years was 3,527,335. As of December 28, 2017, there were 3,424,237 Syrians in Turkey, $1,852,563$ of them male and 1,571,674 female. Looking at the age distribution, approximately $50 \%$ of the migrants were in the $0-18$ age group, $45 \%$ in the $18-60$ age group and $5 \%$ were over 60 .

On 19 July 2018 the total number of Syrians in Turkey was estimated to be $3,541,572$ in total. While 210,177 Syrians were staying in camps called temporary 
accommodation centers, the remaining 3,331,395 people were living outside the camp areas. The numbers of Syrians staying in the camps in particular provinces are given in Table 2 and Figure 3; the detailed information on the names of temporary accommodation centers, provinces where they are located, types of housing etc. is given in Table 3.

Table 2. Distribution of Syrian refugees in the Area of Temporary Protection by temporary shelter centers

\begin{tabular}{|c|c|}
\hline Temporary Shelter Centers & Total \\
\hline Şanlıurfa & 70,650 \\
\hline Gaziantep & 23,095 \\
\hline Kilis & 22,009 \\
\hline Kahramanmaras & 16,374 \\
\hline Mardin & 2,485 \\
\hline Hatay & 16,993 \\
\hline Adana & 26,546 \\
\hline Adiyaman & 8,627 \\
\hline Osmaniye & 14,019 \\
\hline Malatya & 9,379 \\
\hline Total & 210,177 \\
\hline Unsheltered Syrian refugee population & $3,331,395$ \\
\hline Total Syrian refugee population in the country & $3,541,572$ \\
\hline
\end{tabular}

Source: General Directorate of Migration Management, 2018. 
Figure 3. Distribution of Syrian refugees in the Area of Temporary Protection by temporary shelter centers

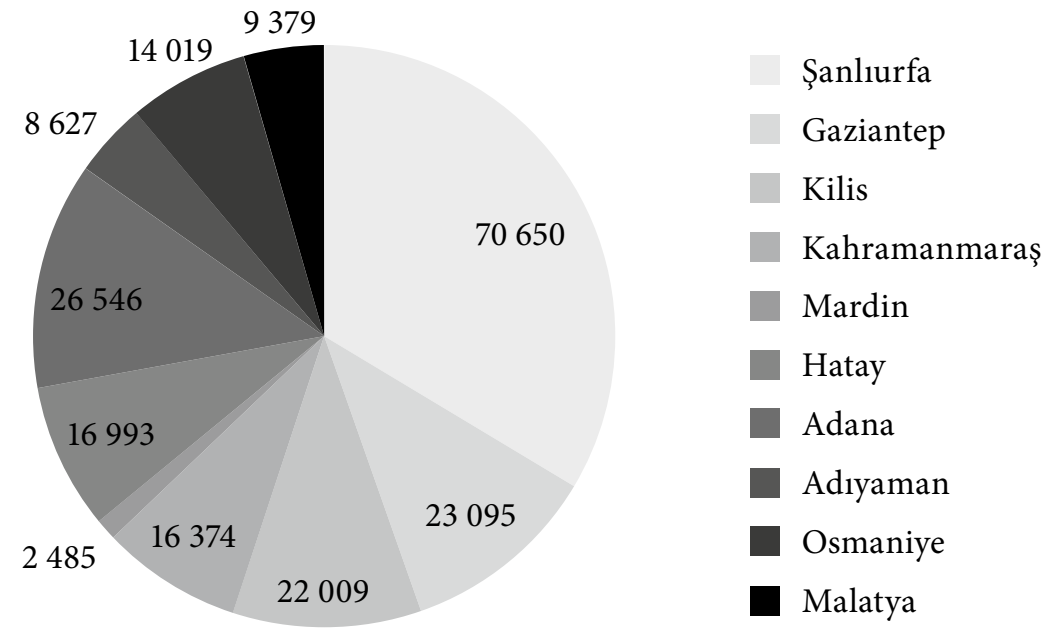

Table 3. Accommodation centers and features by province

\begin{tabular}{|c|c|c|c|c|c|c|}
\hline City & $\begin{array}{l}\text { Temporary } \\
\text { accommodation centers }\end{array}$ & \multicolumn{2}{|c|}{ Housing Types } & \multicolumn{2}{|c|}{ Others } & Total \\
\hline \multirow{4}{*}{ Hatay } & Altınozu Container City & 2056 & Container & 8,354 & Syrian & \multirow{4}{*}{17,116} \\
\hline & Yayladagi Container City & $\begin{array}{r}776 \\
32\end{array}$ & $\begin{array}{l}\text { Container } \\
\text { prefab. concrete } \\
\text { shelter }\end{array}$ & 3,716 & Syrian & \\
\hline & Apaydin Container City & 118 & Container & 5,046 & Syrian & \\
\hline & Guvecci Tent City & 824 & Tent & & Syrian & \\
\hline \multirow[b]{4}{*}{ Gaziantep } & İslahiye Tent City & 1552 & Tent & 5,821 & Syrian & \multirow[b]{4}{*}{22,960} \\
\hline & Karkamis Tent City & 1578 & Tent & 4,722 & Syrian & \\
\hline & Nizip 1 Tent City & 1873 & Tent & 8,623 & Syrian & \\
\hline & Nizip 2 Container City & 908 & Container & 3,794 & Syrian & \\
\hline \multirow[b]{4}{*}{ Sanliurfa } & Ceylanpinar Tent City & 4972 & Tent & 17,781 & Syrian & \multirow[b]{4}{*}{70,025} \\
\hline & Akcakale Tent City & 6461 & Tent & 22,880 & Syrian & \\
\hline & Harran Container City & 2069 & Container & 10,162 & Syrian & \\
\hline & Suruc Tent City & 7028 & Tent & 19,202 & Syrian & \\
\hline
\end{tabular}




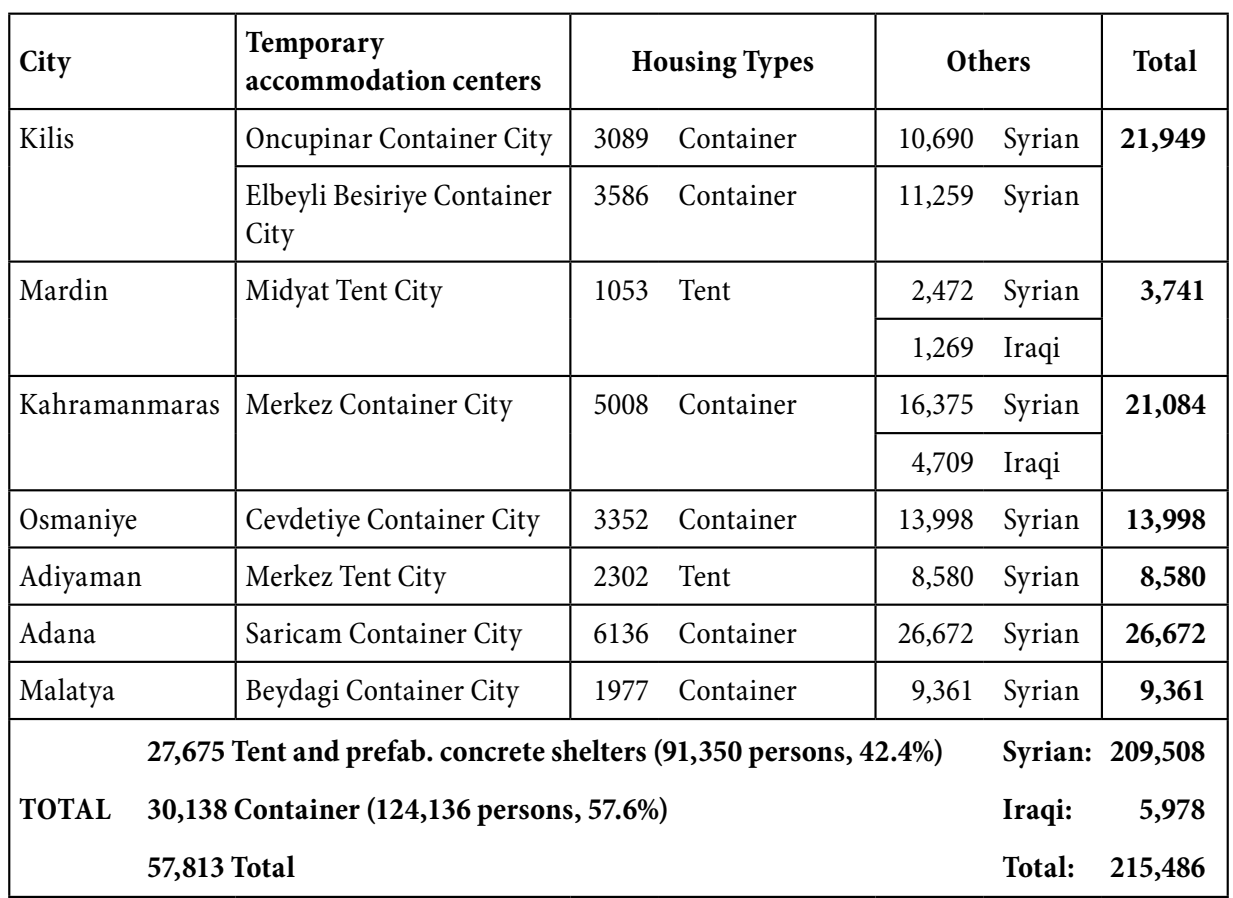

Source: AFAD, 2018.

As can be seen, in ten provinces there are 20 temporary shelter centers consisting of tent-cities and container-cities. According to the data obtained from AFAD, 209,508 of the 215,486 people in these temporary accommodation centers are Syrians.

The temporary sheltering centers, which have been established and maintained to enable Syrians to survive and provide for their basic needs, have continued to serve since the beginning of the civil war under the control of AFAD and the Turkish Red Crescent (Photo 2). Interestingly, some Syrians who have taken refuge in Turkey to escape the fighting and have been staying in temporary accommodation give the name "Afad" to their newborn children. The report published by AFAD in August 2015 on temporary accommodation centers provides the following information:

Even though the Syrian citizens residing in the sheltering facilities are offered services with the status of "guest" in Urfa and other cities within the scope of the activities of AFAD, it is seen that the efforts surpass merely providing temporary shelter. In the areas where centers of administration and registry and gendarmerie, the Turkish Red Crescent, a military hospital, schools, service 
groups, a parking area and a water tank is to be found, many other components are offered for the personal needs and development of the residents, such as worship areas, hairdressers, resting salons, sports areas, children's playing areas and promenade areas. While vocational courses such as carpet weaving, handcrafts and painting are offered in the recreational facilities, the need for nutrition is met inside the shopping centers through the nutrition cards granted by AFAD. Getting informed on the developments taking place in their countries through the Internet cafés and the television salons, the Syrians can also benefit from the psychosocial support offered by the Ministry of Family and Social Policy, coordinated by AFAD. Pre-school and primary school activities are carried out by the collaboration of AFAD and the Ministry of National Education, whereas those of age who do not possess passports can benefit from the Turkish universities. In the sheltering facilities, where tremendous effort is displayed in order for the social life to carry a course as natural as possible, many marriages and births take place. Many families who have taken refuge in our country from the conflict name their children "Afad", to show their appreciation for the help provided (AFAD, 2015, pp. 46-48).

Photo 2. A snapshot of a container house within a Temporary Accommodation Center for Syrian refugees

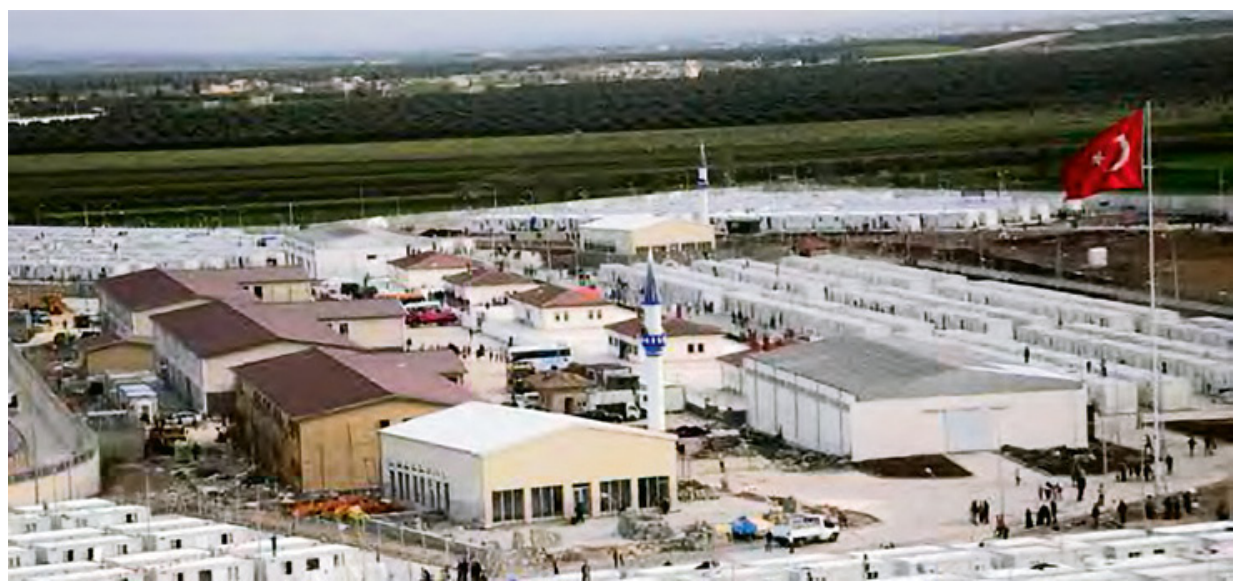

Source: AFAD, 2017b. 


\section{Status of Syrians in General and the Status of Syrians Living in Şanlıurfa in Numerical Data}

According to the data gathered by the Şanlıurfa Directorate of Migration Administration, a total of 451,731 people lived in Şanlıurfa province as of December 2017, with 79.476 persons in 5 camps and 372,55 people outside camps. The 29\% $(131,173)$ of the Syrians living in the province of Şanliurfa were living on their own in the city of Şanlıurfa, which comprises the central districts of Şanlıurfa province (Eyyubiye, Haliliye and Karakopru). According to the data obtained from the Directorate of Migration Management of the Governorship of Şanlıurfa, the Syrians who remained in camps stayed in 4 cities - Ceylanpınar, Akcakale, Harran and Suruc districts - located close to the Syrian border (Tables 4 and 5).

Table 4. Districts where Syrians reside in camps

\begin{tabular}{|l|c|}
\hline District Name & Persons \\
\hline Ceylanpinar & 19,858 \\
\hline Akcakale & 24,546 \\
\hline Harran & 11,398 \\
\hline Viransehir & $*$ \\
\hline Suruc & 23,624 \\
\hline Total & 79,476 \\
\hline
\end{tabular}

Source: Sanliurfa Governorship Directorate of Migration Management, December 2017.

As to Syrians living on their own in Şanlıurfa province, 131,173 of them are living on their own in Şanlıurfa city (Eyubiye, Haliliye and Karakopru), 73,773 in Suruc, 28,321 in Akcakale, 22,910 in Viransehir, 15,340 in Harran, 14,410 in Ceylanpinar, 11,432 in Birecik, 8584 in Siverek, 6443 in Bozova, 2485 in Hilvan and 2007 in Halfeti (Table 5). 
Table 5. Number of Syrians by district

\begin{tabular}{|l|c|}
\hline District Name & Persons \\
\hline Central Districts & 131,173 \\
\hline Akcakale & 82,084 \\
\hline Birecik & 22,963 \\
\hline Bozava & 7,696 \\
\hline Ceylanpinar & 16,019 \\
\hline Halfeti & 2,391 \\
\hline Harran & 22,963 \\
\hline Hilvan & 2,566 \\
\hline Siverek & 10,425 \\
\hline Suruc & 77,155 \\
\hline Viransehir & 23,245 \\
\hline Total & 451,731 \\
\hline
\end{tabular}

Source: Şanlıurfa Governorship Directorate of Migration Management, December 2017.

As of 23 July 2018, a total of 70,025 Syrians took shelter in Şanlıurfa, Ceylanpinar, Akcakale and Suruc in tents and Harran container houses (AFAD, 2018). In other words, 13-15\% of Syrians in Şanlıurfa province live in camps, while the overwhelming majority live independently in cities and towns. As can be seen in Tables 4 and 5 above, Syrians in general are living in certain areas (Şanlıurfa City) and spread throughout the province of Şanlıurfa - which is an issue that leads to the problems of employment and social integration. 


\section{Integration}

In the Glossary of Immigration prepared by the International Organization for Migration (IOM) the word "integration" is used in the context of migrants as a part of society in which they live as individuals or groups. The requirements the receiving communities need to meet to incorporate migrants vary by country. However, integration is not the sole responsibility of either of the parties: both the immigrants themselves and the host states, institutions and communities are responsible for the process of integration (see Yardim, 2017, p. 110).

The concept of what is called butunlesme in Turkish and translates into English as "integration" encompasses collective-specific various institutions and organizations or associations bearing an identifiable set of qualities, involving ethnic and cultural groups, and the situation of complementarity among the various communities; it carries the notions of intertwining, fusing and harmony. "Integration" points to a process before anything else: a process of creating a model in which individuals or groups become a part of the society and its institutions in order to live in interdependence and harmony. At the same time this process involves individuals accepting as their own the basic values and beliefs of the community or group they are in, and thus adopting the sociocultural values of the host society and becoming compatible with it; in other words, this process means "integration" of their basic values (Yavuz, 2013, p. 616, citing Altintas, 2008, p. 38-39).

According to Esser (as cited by Sahin), integration is divided into two categories: "system integration" and "social integration". System integration means that the host society accepts immigrant groups in a harmonious relationship with the host group, without tension. However, social integration differs from system integration: According to Esser, the field of social integration has four aspects, i.e. a) acculturation, b) socio-economic-political status, c) interaction and d) identity. According to him, social integration depends on these four dimensions and the interaction between them (Sahin, 2017, pp. 29-30, citing Esser, 2000, pp. 56-61).

Acculturation refers to immersion of individuals in the new society. Socioeconomic and political status refers to the social, economic and political rights of individuals in the new social order in which they are included. Interaction involves the new members of the community and the host community and necessitates mutual communication. Identity is described in the context of where one perceives themselves in social life. When these four dimensions are evaluated in 
terms of ethnic culture, ethnic community, host society and culture of host society, Esser states that four different models of integration can be distinguished: multiple integration involving adaptation to both cultures; predominance of adaptation to the original culture; assimilation, involving dominance of the new culture; and denial of both cultures, leading to marginalization. According to Esser, social integration is seen as predominance of assimilation and adaptation (Sahin, 2008, p. 230). With the material and spiritual elements that are transmitted through the process of cultural propagation, people and groups from other cultures join a specific culture, and as a result of mutual interaction, a number of changes occur in the traditions and lifestyles of both groups which is a process occurring naturally.

Along with globalization, integration has begun to gain importance and various researchers have attempted to explain this concept. According to the most general definition, to integrate is to transform the scattered elements of the system into conforming compound units with a consistent and coherent structure (Gökçek Karaca, n.d., p. 1). Integration, which can be defined as the process of adapting to the existing social rules and regulations and which can be considered in many aspects - economic, cultural, psychological, sociological and legal - is a complex concept within which it is possible to distinguish e.g. social integration, political integration, cultural integration and economic integration.

For these reasons, Turker and Yildiz believe it is necessary that the concept of integration should be implemented by taking into consideration the economic, social, cultural and psychological primary aspects as well as socio-economic, socio-cultural and socio-psychological secondary aspects of individuals on a legal/political basis (Turker \& Yildiz, 2015, p. 27).

\subsection{Social integration}

In the literature, it is possible to find discussions of the concept of social integration in three broad categories. In the first category, social integration means equal rights for all people. This explanation refers to the notion that integration has its universal laws. At the core of this approach, which corresponds more to a legal dimension, the equality of each person in the sphere of maintaining and upholding their cultural formations is emphasized. The second definition draws attention to social relationships created by integration of different life experiences. The third approach, in essence, has a critical dimension. According to this approach, social integration can be rather problematic as it leads to homogenization of differences that by universal rights should be allowed to coexist. 
The concept of social integration can be expressed also as social union. According to some researchers, social integration means equal rights for all people, while others focus more on the aspect of changes in lifestyles resulting from adaptation to the integrated model. Moreover, social integration can have a negative connotation due to its association with undesirable "unification". Although people may perceive social integration positively or negatively, in fact social integration describes the established order of human relations in a particular society. In other words, social integration is a dynamic process in which social participation and social cohesion are necessary to establish and maintain peaceful social relations. In this context, a social structure can be harmonious only when social order and integrity are protected. Social cohesion is determined by such factors as agreement on values and cultural norms, social pressures faced by individuals or groups, "social exclusion", threats and dangers, status differences, role conflicts, and laws (Gökçek Karaca, n.d., p. 2).

Social integration can be defined as the process of harmonization with the existing social order and rules. Social integration context is mostly used in reference to the phenomenon of migration. People, communities and societies have different characteristics, and migrants also bring their own way of life, their religion and beliefs, and their culture to where they migrate. Therefore disparities that are the result of migration can emerge between people, communities and societies. The process called social integration tends to ensure social cohesion as integration at least begins to reduce these differences, and is a process crucial not only for immigrants but also the native residents of the area.

In the light of the above, it should not be difficult to assess that the Syrians living in the city of Sanliurfa face "exclusion" as one of the most fundamental problems in the context of social integration. Lifestyle differences such as Syrians staying up late, taking daytime breaks in work, or frequently using public spaces at night, combined with the fact that gangs are forming among Syrian youth all this may cause frictions between the local people and the Syrians. Furthermore, and importantly, despite shared faith, the Syrians may experience problems due to sectarian differences between them and the local people. There are various other problems, but in the context of social integration in the city they are overshadowed by the high incidence of begging, theft, drug use and gang-related issues among the Syrians. Crimes and divorces occur frequently among the Syrians, which is a situation the natives of Şanlıurfa are not familiar with.

On the other hand, it is evident that the Syrians doing jobs unsuitable to their skills and education suffer crisis of their social role and identity. For example, a teacher encountered during the field study stated that in Syria he had been 
a lawyer, while a hairdresser used to be an agricultural worker, and a Syrian car washer in Sanliurfa had been an engineer in Syria. However, it was found that Syrians who belonged to the middle class in their own country have formed a subclass after migration. For example, Ammar (one of the participants in the study on Syrian refugees conducted by Deniz and collaborators in Gaziantep) who in Syria worked as a shift engineer in a textile factory and as a mechanical engineer, summarizes the situation as follows:

(Ammar, 39, Aleppo, Arab, unemployed): I was a shift manager in a textile factory in Syria. Under my command, 200 workers were working. I was a mechanical engineer. When I first came to Turkey, I was unemployed for five months. During that time, we sold all our possessions. I even sold my daughter's earrings. I sold everything. In Baspinar, whenever you go to any workplace, they say there is no job. You need to have a connection, you must have a connection inside the factory. If you don't, you can't have a job (Deniz, Hülür \& Ekinci, 2016, p. 1081).

One of the most common problems that Syrians face in social integration is language and communication. As language is the main pillar of a culture, it is an important factor in mutual understanding between cultures. At the same time, it is a communication tool to learn different cultures. However, Syrians who have to live in a country whose language they do not speak may face problems in expressing themselves and traveling as they have difficulty in communicating. According to the results of a report published by AFAD in 2017, the percentage of Syrian guests who are suitably proficient in Turkish is approximately $24 \%$, those moderately proficient - ca. $32 \%$ and those who speak Turkish poorly or not at all - ca. $44 \%$. These rates are similar in the in-camp and out-of-camp context. With regard to gender, males tend to speak Turkish better than females in and outside the camps. Yet although the results are generally similar, the proportion of men outside the camps is higher than women. (AFAD, 2017a, p. 119). A field study conducted in Sanliurfa in December 2017 revealed that the most basic problem experienced by $24 \%$ of Syrians in Sanliurfa was the language problem. It was also found that $52 \%$ had problems related both to language and economic situation (see Benek, Elmastaş, Özcanlı \& Pınar, 2017, p. 64).

\subsection{Economic integration}

Economic integration means adaptation of migrants and groups to the economic conditions that provide them with minimum living conditions in the places to which they migrate. This integration can mostly be achieved through economic integration policies (such as increasing employment opportunities and 
providing benefits and funds) adopted by powerful institutions such as the state. In this aspect, economic integration is the type of integration that immigrants may have the most difficulty with or where their adaptation can be problematic.

In a study conducted by Orhan and Gondogan on the economic impact of Syrian refugees in Turkey these difficulties are as follows (see Budak, Demir, Tan \& Sar1, 2017, p. 548):

- Rents have increased, so it has become progressively difficult to find a residence.

- Stealing in small enterprises has become widespread.

- Unfair competition has emerged between firms employing illegal Syrian workers and those that do not.

- Local residents believe that the employment opportunities offered to Syrians were taken away from them. However, this is not the case: the jobs taken by the Syrian refugees usually involve tasks the local people are unwilling to perform.

- There has been a significant decrease in workers' wage levels.

When considering the Syrians in Şanluurfa in the context of economic integration, Syrian migratory wave far exceeding what Şanlıurfa can support as a city has created the problem of uneven distribution of the already scarce resources. In Şanllurfa, which is a city where job opportunities are very low and consequently unemployment is high, it is becoming progressively difficult for Syrians to find a job: they face unemployment and are thus incapable to meet even their daily basic needs. Moreover, as Benek and Sahap (2015, pp. 499-500) noted, the Syrians have also created cheaper labor market in the city because they accept wages below those offered to local people. Thus most Syrians are forced to work in poor conditions, for low wages and without insurance, being exploited by their employers. It has been observed that house and shop rents are rising as a result of the presence of Syrians in the city. What is more, Syrians entering trade jobs and providing cheap goods and services means that local tradesmen are losing income, and some of them have been forced to close their businesses. This change in the trade labor market is one of the greatest obstacles to local tradesmen's acceptance of Syrians. On the other hand, while the Syrians in the city are struggling to meet their basic needs, their plight is exploited by the emerging middle and upper classes. Hence, the economic integration of Syrians in the city of Şanlıurfa is becoming more difficult. Moreover, the idea that the Syrians are the cause of many economic changes has a negative impact on how the Syrians are perceived by the local people. As revealed in a report published by in $2017,41 \%$ of the indigenous people in Turkey think housing 
prices and rental rates are negatively affected by the arrival of the Syrians; $19 \%$ hold that opinion in regard to social order, $16 \%$ - security, and $21 \%$ - job opportunities and salaries (AFAD, 2017a, p. 10). This provides clues about the role of the Syrians in shaping the public perception of their economic effects.

\subsection{Cultural integration}

According to Martikainen, cultural integration has two aspects: the attitude of individual migrants and groups to local values, rules and behavioral models as well as compliance to them; and the area where the host society responds to the manifestations of cultural life of the migrants. The place of cultural integration is civil society and the media in today's world. Successful and positive integration in a cultural sense manifests itself in the presence of strong ethnic relations (Martikainen, 2010, p. 271). In brief, cultural integration means both the migrants and the indigenous population adapting to or integrating with the cultural values the other party possesses. However, despite geographical proximity, differences between the Syrian and the Turkish population may be too significant to bridge easily and produce an integrated society. The cultural differences between the Syrians in Şanlıurfa city and the indigenous people lie in most basic areas such as clothes, traditions and customs, attitudes and behaviors. This creates a cultural conflict in the city, which in turn makes cultural integration of locals and Syrians difficult.

One of the problems that Syrians most frequently encounter in urban integration is undoubtedly "othering" and social exclusion. "Othering" is a form of discourse that aims to both set apart and weaken people of different identities by treating and referring to them in humiliating and contemptuous ways. Ethnicity, skin color, weight, hair color, physiological characteristics, religion, denomination, gender, age, education, income, region, city, neighborhood, family, profession, culture, intelligence, talent, skill, and other real and imaginary differences may be subjected to otherization (Aslan, 2017, p. 336). Such process of depriving individuals or households of resources or of social ties with a wider community (Cetin, 2016, p. 2010, citing Marshall, 1999) creates social exclusion, which emerges as a result of disagreements in the society, polarization, growing social inequality, increasing unemployment and inability to participate in normal citizen activities, institutions or economic growth. In other words, social exclusion refers to exclusion of individuals, communities or societies, often combined with inequality, deprivation, poverty, unequal treatment, or discriminative social values (Gökçek Karaca, n.d., p. 2). In a previous study conducted in Şanlıurfa city (see: Benek et al., 2017, p. 188), the respondents were to answer the question: 
"If you were given a free house in a neighborhood where the Syrians were busy, would you move there?" 84 out of 102 respondents stated that they did not want to move to such a house even if the state gave it for free (Table 6). This situation demonstrates the depth of the problem, the (lack of) desire of the local respondents to live with the Syrians is the feature of the "decomposition" aspect and the level of acceptance of the Syrians.

Table 6. Responses to the question whether one would move or not, if a free house was given to them in an area where they would have Syrian neighbors and the Syrians were active

\begin{tabular}{|l|l|l|l|l|l|l|l|l|}
\hline \multicolumn{7}{|c|}{ Would you move if a free house was given to you in an area where Syrians are active? } \\
\hline $\begin{array}{l}\text { Do you have Syrian } \\
\text { neighbors? }\end{array}$ & Yes & \multicolumn{2}{l|}{ No } & \multicolumn{3}{l|}{ I need to think } & \multicolumn{2}{l|}{ Total } \\
\hline Yes & Num & Per & Num & Per & Num & Percent & Num & Percent \\
\cline { 2 - 11 } & 14 & $9.5 \%$ & 84 & $56.8 \%$ & 4 & $2.7 \%$ & 102 & $68.9 \%$ \\
\hline No & 7 & $4.7 \%$ & 35 & $23.6 \%$ & 4 & $2.7 \%$ & 46 & $31.1 \%$ \\
\hline Total & 21 & $14.2 \%$ & 119 & $80.4 \%$ & 8 & $5.4 \%$ & 148 & $100 \%$ \\
\hline
\end{tabular}

Source: Benet et al., 2017.

It is also striking that 50 out of the 101 neighbors of Syrians have trouble with the Syrians. Those who do not live next to Syrians but who object to living among them are more striking: 5 out of 23 participants who did not actually have any Syrian neighbors stated that they were having issues with the Syrians (Table 7).

Table 7. Objections to having Syrian neighbours

\begin{tabular}{|l|l|l|l|l|l|l|}
\hline \multicolumn{7}{|c|}{ Would you have objections to having Syrian neighbors? } \\
\hline Do you have Syrian neighbors? & Yes & No & \multicolumn{3}{l|}{ Total } \\
\hline & Num & Percent & Num & Percent & Num & Percent \\
\hline Yes & 50 & $40.3 \%$ & 51 & $41.1 \%$ & 101 & $81.5 \%$ \\
\hline No & 5 & $4.0 \%$ & 18 & $14.5 \%$ & 23 & $18.5 \%$ \\
\hline Total & 55 & $44.4 \%$ & 69 & $55.6 \%$ & 124 & $100 \%$ \\
\hline
\end{tabular}

Source: Benek et al., 2017. 
Moreover, the 83 out of of the 102 participants who have Syrian neigbors state that there are distinct cultural differences between them and the Syrians (Table 8). This offers a clue about the level of integration between the two groups as it shows the percentage of people who actually have Syrian neighbors, have objections to Syrians in general and claim that this is due to significant cultural differences.

Table 8. Opinions of local respondents - who have actual Syrian neighbors or not on whether there is a cultural difference between themselves and the Syrians

\begin{tabular}{|l|l|l|l|l|l|l|l|l|l|}
\hline \multicolumn{7}{|c|}{ Are there have cultural differences between you and the Syrians? } \\
\hline $\begin{array}{l}\text { Do you have Syrian } \\
\text { neighbors? }\end{array}$ & Yes & No & \multicolumn{3}{l|}{ Partly } & \multicolumn{3}{l|}{ Total } \\
\hline & Num & Per & Num & Per & Num & Per & Num & Per \\
\hline Yes & 83 & $56.1 \%$ & 4 & $2.7 \%$ & 15 & $10.1 \%$ & 102 & $68.9 \%$ \\
\hline No & 30 & $20.3 \%$ & 11 & $7.4 \%$ & 5 & $3.4 \%$ & 46 & $31.1 \%$ \\
\hline Total & 113 & $76.4 \%$ & 15 & $10.1 \%$ & 20 & $13.5 \%$ & 148 & $100.0 \%$ \\
\hline
\end{tabular}

Source: Benek et al., 2017.

Similarly, in another study (AFAD, 2017) $21 \%$ of Syrians said they could not adapt to the social life in Turkey; $33 \%$ stated that they did not feel they belonged to the local society (AFAD, 2017a, p. 10). Furthermore, the same study revealed that $44 \%$ of the Syrians perceived cultural differences, $40 \%$ differences in social life, $29 \%$ moral differences, $18 \%$ differences in forms of religious worship, $60 \%$ the psychological changes resulting from war experiences and the $72 \%$ material insufficiencies, which constituted an obstacle to adaptation (AFAD, 2017a, p. 10), revealing the barriers to social and cultural integration between the two peoples.

\section{Conclusion}

A human being is a socio-cultural entity and every human group, tribe or society has its unique beliefs, cultures and values. As people migrate, they bring with them all the beliefs and values they uphold.

Due to the civil war in Syria that began in 2011, millions of Syrians have been forced to migrate inside and out of the country. They went to many European countries (particularly to Germany), to Turkey, Iraq and Iran as well as to neighboring countries such as Jordan, Saudi Arabia, Egypt, Libya and other Middle 
East Arab countries. Widespread incidents of violence in Syria and the civil war continuing longer than expected and not being over yet have prevented Syrians from returning to their country and forced them to remain in the places to which they migrated. As the Syrians have brought with them their beliefs and cultures, they encounter problems in integrating and are in the center of a cultural confrontation. Undoubtedly, Turkey comes out as one of the countries most afflicted by these problems as the population of Syrians in Turkey at the end of December 2017 exceeded 3.5 million, with Istanbul and Sanliurfa being the cities with the largest Syrian populations in Turkey.

There are significant cultural differences between the Syrian diaspora in Şanlıurfa and the locals. These cultural differences make it difficult to achieve cultural harmony between the indigenous people and the Syrians. The adaptation problems the migrants experience also cause a serious cultural conflict between the people of the region and the Syrians. According to the information obtained from field studies and observations, the local people feel discomfort towards the guests and even indulge in hate speech against Syrian individuals, which exacerbates the aspect of "decomposition" between the two peoples. This "decomposition" shows us the scale of risk, and the situation is likely to cause future problems with integrating the peoples of both countries. The most important point is that it shows that the desire to "live together" will continue to gradually weaken.

\section{REFERENCES}

Adıgüzel, Y. (2016). Göç Sosyolojisi. Ankara: Nobel Akademik Yayıncılık.

AFAD (Afet ve Acil Yönetim Başkanlığı) (2017a). Türkiye'deki Suriyelilerin Demografik Görünümü, Yaşam Koşulları ve Gelecek Beklentilerine Yönelik Saha Araştırması [a report]. Retrieved from https://www.afad.gov.tr/upload/Node/25337/ xfiles/17aTurkiye_deki_Suriyelilerin_Demografik_Gorunumu_Yasam_Kosullari_ve_Gelecek_Beklentilerine_Yonelik_Saha_Arastirmasi_2017.pdf

AFAD (Republic of Turkey Prime Ministry Disaster and Emergency Management Authority) (2017b). Field Survey On Demographic View, Lıving Conditions 12 And Future Expectations Of Syrians In Turkey. Retrieved from https://www.afad.gov.tr; https://www.afad.gov.tr/upload/Node/25335/xfiles/17b-Field_Survey_on_Demographic_View_Living_Conditions_and_Future_Expectations_of_Syrians_in_Turkey_2017_English_1.pdf 
AFAD (Republic of Turkey Prime Ministry Disaster and Emergency Management Authority) (2015). Where Fire Cannot Burn Man (By Özge Aydın) August 2015. (pp. 40-49). Retrieved from https://www.afad.gov.tr; https://www.afad.gov.tr/upload/Node/3508/xfiles/agustos-dergi.pdf

AFAD (Republic of Turkey Prime Ministry Disaster and Emergency Management Authority) (2018). Retrieved from https://www.afad.gov.trhttps://www.afad.gov.tr/ upload/Node/2374/files/23_07_2018_Suriye_GBM_Bilgi_Notu.pdf

Aslan, C. (2017). New Others of Turkey: Syrians. Route Educational and Social Science Journal, 4(8), 335-341.

Benek, S., Baydemir, R., Elmastaş, N., Yetmen, H., Özcanlı, M., \& Pınar, A. (2018). Suriyeli Esnafların Urfa’nın Esnaf İsgücü Piyasasına Etkileri Üzerine Yapılmış Bir Alan Çalışmasının Sonuçları Üzerine Bir Değerlendirme. III. Ines Uluslararası Eğitim ve Sosyal Bilimler Kongresi Özet Kitapçı̆̆ı (28 Nisan-01 Mayıs 2018- Alanya/Antalya).

Benek, S., Elmastaş, N., Özcanll, M., \& Pınar, A. (2017). The Investigation of the Effect of Syrians on the Small Trades Labor Market in Terms of Social Integration: The Case of Sanliurfa City. Harran University Scientific Research Board (HÜBAK) (Project No: 16178), Unpublished Project Report. Şanlıurfa.

Benek, S., \& Pınar, A. (2016). Türkiye’nin Suriyeli Sığınmacılara Yönelik Uyguladığ 1 Misafirlik Politikası Üzerine Bir Değerlendirme. Madrid: İBAD E-book. Retrieved from http:// dergipark.gov.tr/uploads/files/08e6/f6cd/08f1/59305864c0347.pdf

Benek, S., \& Şahap, A. (2015). Suriye İç Savaşının Türkiye’nin Güneydoğusundaki Sınır ve Sınıra Yakın İllerin Sosyo-Ekonomik Yapısına Etkisi. İnternational Science and Technology Conference, 2-4.

Bill, J., \& Düvell, F. (2002). Irregular Migration: The Dilemmas of Transnational Mobility. Cheltenham (UK) \& Northampton (US): Edward Elgar.

Budak, P., Demir, M. S., Tan, M., \& Sarı, M. (2017). Yerel Halkın Algısında Suriyeli Sığınmacılar ve Toplumsal Etkileri: Elazığ İli Örneği. Akademik Sosyal Araştırmalar Dergisi, 5(62), 543-564.

Castles, S., \& Alastair, D. (2000). Citizenship and Migration: Globalization And The Politics of Belonging. New York: Routledge.

Castles, S., \& Godula, K. (1973.). Immigrant Workers and Class Structure in Western Europe. Oxford: Oxford University Press.

Castles, S. (2002). Migration and Community Formation Under Conditions of Globalization. International Migration Review, 36(4), 1143-1168.

Castles, S. (2003). Towards a Sociology of Forced Migration and Social Transformation. Sociology, 37(1), 13-34.

Castles, S. (2004). Why migration policies fail. Ethnic and racial studies, 27(2), 205-227.

Castles, S. (2009). Development and Migration-Migration and Development: What Comes First? Global Perspective and African Experiences. Theoria: A Journal of Social and Political Theory, 1-31. 
Castles, S. (2010) Understanding Global Migration: A Social Transformation Perspective. Journal of Ethnic and Migration Studies, 36(10), 1565-1586.

Castles, S. (2012). Migration and Social Transformation. In M. Martinielllo \& J. Rath (eds.), An Introduction to International Migration Studies. European Perspectives (pp. 155-178). Amsterdam: Amsterdam University Press.

Castles, S., Hein De, H., \& Miller, M. J. (2013). The Age of Migration: International Population Movements in The Modern World. Palgrave Macmillan.

De Haas, H. (2010). Migration and Development: A Theoretical Perspective. International Migration Review, 44(1), 227-264.

Deniz, Ç., Hülür, B., \& Ekinci, Y. (2016). Göç, Strateji ve Taktik: Suriyeli Sığınmacıların Gündelik Hayat Deneyimleri. The Journal of International Social Research, 9(42), 1077-1087.

Directorate of Migration Management of Şanlıurfa Governorship, December 2017 [unpublished statistical data].

Düvell, F. (2004a). Highly Skilled, Self-employed and Illegal Immigrants from Poland in United Kingdom. Warsaw: Centre for Migration Studies Working Paper, 4.

Düvell, F. (2004b). Polish Undocumented Immigrants, Regular High-Skilled Workers and Entrepreneurs in the UK. Institute For Social Studies Working Paper, 54, 1-28.

Düvell, F. (2006a). Crossing the Fringes of Europe: Transit Migration in the EU's Neighbourhood. Centre on Migration, Policy and Society.

Düvell, F. (2006b). Europäische und internationale Migration. Einführung in historische, soziologische und politische Analysen. Hamburg: Lit Verlag Dr W. Hopf.

Düvell, F. (2008). Clandestine Migration in Europe. Social Science Information, 47(4), 479-497.

Düvell, F. (2009). Migration, Minorities And Marginality: New Directions in Europe migration Research. In C. Rumford (ed.), The SAGE Handbook of European Migration Research (pp. 328-348). London: SAGE.

Düvell, F. (2011a). Irregular Immigration, Economics and Politics. DICE Report, 9(3), 60.

Düvell, F. (2011b). Paths into Irregularity: The Legal and Political Construction of Irregular Migration. European Journal of Migration and Law, 13(3), 275-295.

Düvell, F. (2012). Transit Migration: a Blurred and Politicised Concept. Population, Space and Place, 18(4), 415-427.

Düvell, F. (ed.). (2005). Illegal immigration in Europe. Palgrave Macmillan. [Digital edition]

Erdoğan, M. (2014). Türkiye'deki Suriyeliler: Toplumsal Kabul ve Uyum Araştırması [a report]. Hacettepe Üniversitesi Göçve Siyaset Araştırmaları Merkezi.

Göç İdaresi Genel Müdürlüğü. (2019). Retrieved from http://www.goc.gov.tr; http:// www.goc.gov.tr/icerik6/temporary-protection_915_1024_4748_icerik

Gökçek Karaca, N. (n.d.). Türkiye ve Geçiş Ekonomilerinde Sosyal Enterasyon. Retrieved from https://www.avekon.org/; https://www.avekon.org/papers/870.pdf. 
Gutman, R. (2016, April 4). Europe’s migrants, Turkey's Problem: As Migrant Routes Are Blocked to The EU, Tensions Rise Between Syrian Migrants and Their Turkish Hosts. Politico. Retrieved from https://www.politico.eu/article/europes-migrantsturkeys-problem/

Ihlamur-Öner, G., \& Şirin Öner, A. (2016). (Der) Küreselleşme Çağında Göç: Kavramlar Tartışmalar. İstanbul: İletişim Yayınları.

İçduygu, A., \& Şimşek, D. (2016). Syrian Refugees in Turkey: Towards Integration Policies. Turkish Policy Quarterly, 15(3), 59-69.

Joppke, C. (ed.). (1998). Challenge To The Nation-State: Immigration In Western Europe And The United States. Oxford University Press On Demand.

Kaya, M. (2015). Komşuda Misafirlik: Suriyeli Sığınmacılarca Kurulmuş Mülteci Derneklerinin Perspektifinden Türkiye'de Yaşamak. The Journal of Academic Social Science Studies, 39, pp. 263-279. DOI: http://dx.doi.org/10.9761/JASSS3050

Kaya, M. (2017). Türkiye'deki Suriyeliler: İç İçe Geçişler ve Karşılaşmalar. Hiperlink Yayınları.

Keser, İ. (2011). Göç ve Zor: Diyarbakır Örneğinde Göç ve Zorunlu Göç. Ankara: Ötopya Yayınevi.

Kirişçi, K. (2014). Misafirliğin Ötesine Geçerken Türkiye’nin Suriyeli Mülteciler Sınavi. Uşak: Brooking Enstitüsü.

Koyuncu, A. (2014). Kentin Yeni Misafirleri Suriyeliler. Konya: Çizgi Kitabevi.

Legomsky, S. H. (1987). Immigration and the Judiciary: Law and Politics in Britain and America. Oxford: Oxford University Press.

Martikainen, T. (2010). Din, Göçmenler ve Entegrasyon. Marmara Üniversitesi İlahiyat Fakültesi Dergisi, 38(1), 263-276.

Mazlumder, (2014). Kamp Dışında Yaşayan Suriyeli Kadın Sığınmacılar Raporu. Mazlumder Kadın Çalışmaları Grubu. Retrieved from http://mazlumder.org/webimage/MAZLUMDER\%20KAMP\%20DI\%C5\%9EINDA\%20YA\%C5\%9EAYAN\%20 KADIN\%20SI\%C4\%9EINMACILAR\%20RAPORU(22).pdf

McHuga, J. (2014). Syria: From the Great War to Civil War. London: Sagi Boks.

Morrison, L. (2014). Discrimination and the Abuse of Human Rights Characterises the Current Plight of Palestinian Refugees from Syria. Journal of Palestinian Refugee Studies, 316(2102), 1-8.

Ozatesler, G. (2014). Gypsy Stigma and Exclusion in Turkey, 1970: The Social Dynamics of Exclusionary Violence. New York: Palgrave Macmillan.

Papadopoulou-Kourkoula, A. (2008). Transit Migration: The Missing Link Between Emigration and Settlement. Springer [Digital edition].

Şahin, B. (2017). Almanya'daki Türk Göçmenlerin Sosyal Entegrasyonunun Kuşaklararası Karşılaştırması: Kimlik ve Ait Hissetme. Haccettepe Üniversitesi Türkiyat Araştırmaları Dergisi, (8), 227-252.

Şimşek, D. (2018). Transnational Activities of Syrian Refugees in Turkey: Hindering or Supporting İntegration. International Migration, 57(2), 268-282. https://doi.org/10.1111/ imig. 12489 
Terzioğlu, A. (2018). The Banality of Evil and the Normalization of the Discriminatory Discourses Against Syrians in Turkey. Anthropology of the Contemporary Middle East and Central Eurasia, 4(2).

Türker, D., Yıldız, A. (2015). "Göçmenlerde Sosyo-Psikolojik Entegrasyon Analizi". In D. Şeker, I. Sirkeci \& M. Yüceşahin (eds.), Göç ve Uyum (pp. 23-34). London: Transnational Press.

The Office of the United Nations High Commissioner for Refugees (UNHCR). (2018). Syria Regional Refugee Response. Retrieved from https://data2.unhcr.org/en/situations/syria?page $=1$

Ülker, E. (2008). Assimilation of the Muslim Communities in the First Decade of the Turkish Republic (1923-1934). European Journal of Turkish Studies. Social Sciences on Contemporary Turkey. Retrieved from https://journals.openedition.org/ ejts/822\#text

Ülker, E. (2008). Assimilation, Security and Geographical Nationalization in Interwar Turkey: The Settlement Law of 1934. European Journal of Turkish Studies. Social Sciences on Contemporary Turkey, (7). Retrieved from https://journals.openedition. org/ejts/2123\#text

Van Dam, N. (2017). Destroying in Nation: The Civil War In Syria. London-New York: I.B.Tauris.

Yalçın, C. (2004). Göç Sosyolojisi. Ankara: Anı Yayınları.

Yardım, M. (2017). Göç ve Entegrasyon Politikaları Işı̆̆ında Fransa'da Toplumsal Kabul. Göç Araştırmaları Dergisi, 3(2), 100-136.

Yassin-Kasap, R., \& Al Shami, L. (2016). Burning Country: Siyrians in Revolution and War. London: Pluto Press.

Yavuz, S. (2013). Göç, Entegrasyon ve Din: Avrupa'da Yasayan Türkler Baglamında Bir Degerlendirme. Uluslararası Sosyal Arastırmalar Dergisi, 6(26), 610-623. 